\title{
Management Accounting and the Shortcomings of Current Performance Measurement Systems
}

\section{Davood Askarany ${ }^{1 *}$ and Hassan Yazdifar ${ }^{2}$}

${ }^{1}$ Business School, Department of Accounting and Finance, University of Auckland, New Zealand

${ }^{2}$ Salford Business School - University of Salford, UK

\begin{abstract}
Balanced Scorecard (BSC) is one of the most talked about performance measurement systems in the management accounting literature in the past two decades. In this paper, we argue that the BSC has failed to perform as a comprehensive performance measurement systems though it focuses on both financial and nonfinancial indicators. By presenting a historical review of the BSC, we explore the key shortcomings of the BSC and discuss the steps which have been taken to address the shortcomings of the BSC since its introduction in the 1990s. And finally, we present our research findings regarding the shortcomings of the BSC in practice.
\end{abstract}

Keywords: Balanced scorecard; Risk; Stakeholders' Rights; Performance measurement; Diffusion of innovation

\section{Introduction}

The present literature has noticeably highlighted the effectiveness and the usefulness of the BSC as a performance measurement systems for the businesses [1-11]. The overall assessment is that the BSC can contribute to organisations' performance if fully implemented. It enables organisations to clarify their visions and strategies and translate them into actions. It provides feedback around both the internal business processes and external outcomes to (continuously) improve strategic performance and results. When fully deployed, the BSC transforms strategic planning from an academic exercise into the nerve centre of an enterprise [12-14].

Nonetheless, despite its suggested merits, research on the diffusion of the BSC indicates that its adoption rate is lower than those of other managerial tools such ABC [14-16]. So, it is unclear if the BSC has any shortcoming/s that might have contributed to its slow adoption in the current ever-changing environment of the $21^{\text {st }}$ century.

In the following sections, we present a general overview of the BSC, including its different generations from birth to the present and suggest what need to be done to improve the BSC as reliable and comprehensive performance measurement tool.

\section{A General Overview of the Development of the BSC}

Recognising the shortcomings of relying on financial indicators alone (as a performance measurement tool), Kaplan and Norton (1992) introduced the first generation of the BSC to provide a better prescription as to what companies should measure to 'balance' the financial and non-financial perspectives by linking non-financial measures with a financial perspective in four areas of performance concerned with financials, internal process, customers and innovation and learning. According to Figure 1, the main aim of the first generation of the BSC was getting a grip on the organisation trough control, monitoring and reporting [12-14,17].

However, the first generation of the BSC has paid less attention to cause and effect relationship/s between 4 perspectives (financials, internal process, customers and innovation and learning). To address the shortcomings of the first generation of the BSC, the second generation BSC, the third generation BSC and the fourth generation BSC have been introduced [18-20].
The second generation of the BSC tries to address the cause and effect relationship between 4 perspectives as shown if Figure 2 below:

However, both the first and the second generations of the BSC have failed to use the BSC as a tool for implementing the strategy. So, the third generation of the BSC has been introduced as an integrated strategic performance measurement system that helps organisations to translate strategic objectives into relevant performance measures and learn them as shown in Figure 3 as follows:

Though the third generation of the BSC addresses some shortcomings of the previous generations of the BSC, it has failed to take into consideration the impact of external factors on the performance of organisations. In other words, considering all organisational factors including both financial and non-financial factors as well as establishing a cause and effect relationship between these factors and providing a link between KPI's (key performance indicators) and organisational strategy is great but not enough. Indeed, no individual organisation

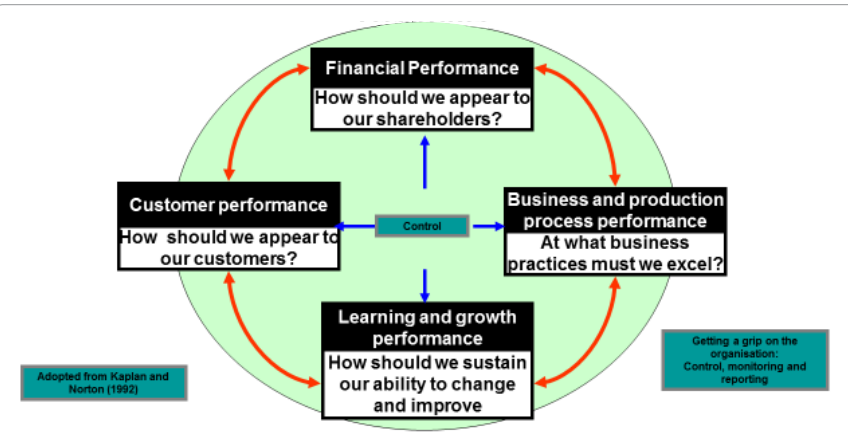

Figure 1: The First generation: Four basic balanced scorecard perspectives.

*Corresponding author: Davood Askarany, Business School, Department of Accounting and Finance, University of Auckland, Private Bag: 9201 Auckland, New Zealand, Tel: 64-9-9235785; E-mail: d.askarany@auckland.ac.nz

Received June 23, 2016; Accepted December 30, 2016; Published January 15 2017

Citation: Askarany D, Yazdifar H (2017) Management Accounting and the Shortcomings of Current Performance Measurement Systems. Int J Account Res 5: 146. doi:10.4172/2472-114X.1000146

Copyright: @ 2017 Askarany D, et al. This is an open-access article distributed under the terms of the Creative Commons Attribution License, which permits unrestricted use, distribution, and reproduction in any medium, provided the original author and source are credited. 
Citation: Askarany D, Yazdifar H (2017) Management Accounting and the Shortcomings of Current Performance Measurement Systems. Int J Account Res 5: 146. doi:10.4172/2472-114X.1000146

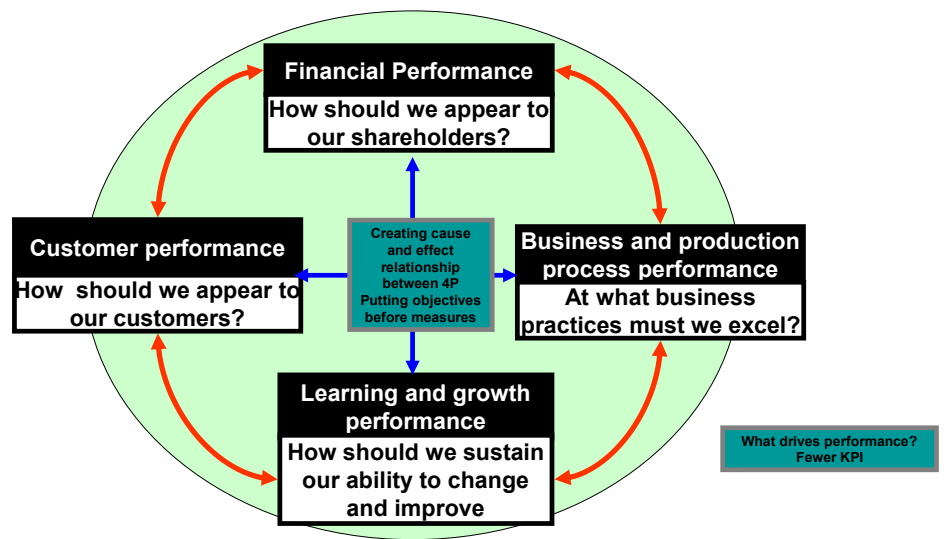

Figure 2: The second generation balanced scorecard.

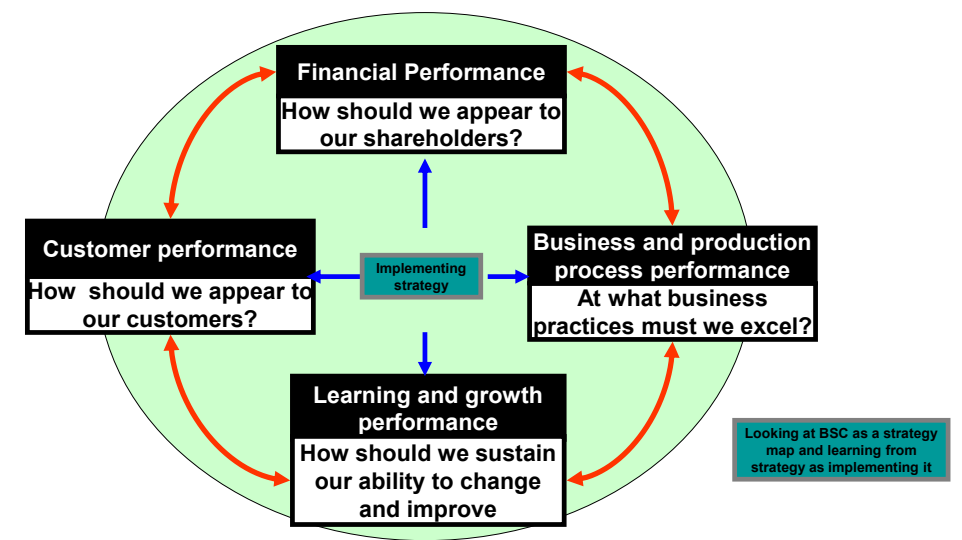

Figure 3: The third generation balanced scorecard.

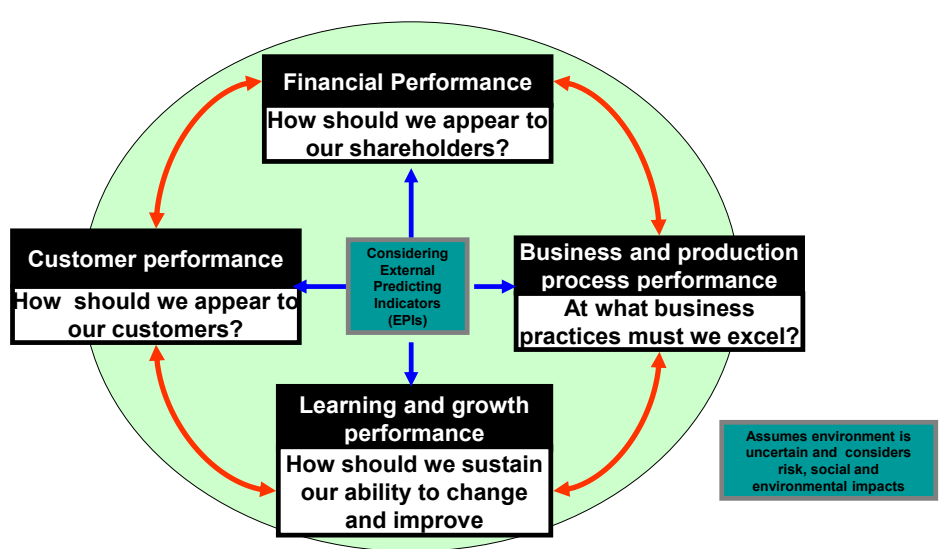

Figure 4: The fourth generation balanced scorecard.

can totally ignore the impacts of its operation/s on external factors (including the environment) and vice versa. And therefore, no performance measurement tool can be considered as comprehensive unless it discloses the interaction effects of external factors such as environment and risk on organisations' performance.

To address the above shortcomings, the fourth generation of the BSC has been introduced as shown in Figure 4 as follows:

\section{The Shortcomings of the BSC in Practice}

To get the better picture of the shortcomings of the BSC in practice, we sent a questionnaire to 400 registered members of Chartered Institute of Management Accountant (CIMA) in New Zealand in 2011 and asked them about the diffusion of the BSC in their organisations as well as the shortcomings of the BSC in practice. We received 142 useable survey responses (plus 10 not-completed or not delivered), with the satisfactory response rate of $35.5 \%$. 
Citation: Askarany D, Yazdifar H (2017) Management Accounting and the Shortcomings of Current Performance Measurement Systems. Int J Account Res 5: 146. doi:10.4172/2472-114X.1000146

Page 3 of 3

The findings revealed that only $21.4 \%$ of respondents were using the BSC as an accepted tool, $4.3 \%$ were using it on a trial basis, $27.10 \%$ were considering it for future use and the remaining $47.2 \%$ either didn't discuss its implementation or decided not to use it. Exploring the shortcomings of the BSC, the targeted respondents (in an open-ended question in the distributed questionnaire) were asked to list the weaknesses/shortcomings of the BSC. According to the findings, the respondents' points of view were that ignoring the risks, environmental and sustainability factors as well as neglecting the concerns/rights of other relevant stakeholders (besides customers) are the key shortcomings of the BSC, which could undermine its diffusion in practice.

\section{Implications and Conclusions}

The BSC as a performance measurement technique has received considerable attention in the literature. Although a number of BSC generations have been introduced to address some of the shortcomings of the BSC in practice, studies investigating the diffusion of the BSC indicate that the adoption of the BSC by organisations is relatively low (up to 30\%). This level of adoption for the BSC raises an important question: Does the BSC still suffer from any shortcoming that could undermine its diffusion?

Investigating the diffusion of BSC in practice, the findings show that only $21.4 \%$ of organisations have adopted and accepted the BSC and a further $4.3 \%$ of organisations have implemented the BSC on a trial basis (but not accepted it).

Exploring the shortcomings of the BSC, the findings show that ignoring the risk, environmental and sustainability factors as well as neglecting the concerns/rights of other relevant stakeholders (besides customers) are the key shortcomings of the BSC from adopters' points of view. So, further research is needed to find out how we can include external factors such as risk and environment factors into four perspectives of the BSC to contribute to its diffusion in practice.

\section{References}

1. Askarany D (2000) Impact of influencing factors on diffusion of cost and management accounting innovations. Sixth Interdisciplinary Perspectives on Accounting Conference (IPA) Colloquium. Manchester, UK: IPA.

2. Askarany D (2003a) An Investigation into the Diffusion of Management Accounting Innovations. Business School. PhD Thesis, Adelaide: University of South Australia. p: 343

3. Askarany D (2003b) An Overview of the Diffusion of Advanced Techniques
Advanced Topics in Global Information London: IDEA Group Publishing 2: 225-250.

4. Askarany D (2005) Diffusion of Innovations in Organizations. IDEA Group Publishing, pp: 853-857.

5. Askarany D (2006) Characteristics of adopters and organizational changes. Thunderbird International Business Review 48: 705-725.

6. Banker RD, Chang H, Pizzini M (2011) The judgmental effects of strategy maps in balanced scorecard performance evaluations. International Journal of Accounting Information Systems 12: 259-279.

7. Creamer G, Freund Y (2010) Learning a board Balanced Scorecard to improve corporate performance. Decision Support Systems 49: 365-385.

8. Dilla WN, Steinbart PJ (2005) The effects of alternative supplementary display formats on balanced scorecard judgments. International Journal of Accounting Information Systems 6: 159-176.

9. Martinsons M, Davison R, Tse D (1999) The balanced scorecard: a foundation for the strategic management of information systems. Decision Support Systems 25: 71-88.

10. Wu IL, Chang $\mathrm{CH}$ (2012) Using the balanced scorecard in assessing the performance of e-SCM diffusion: A multi-stage perspective. Decision Support Systems 52: 474-485.

11. Yigitbasioglu OM, Velcu O (2012) A review of dashboards in performance management: Implications for design and research. International Journal of Accounting Information Systems 13: 41-59.

12. Kaplan R, Norton D (1992) The Balanced Scorecard: Measures that Drive Performance. Harvard Business Review 70: 71-79.

13. Kaplan RS., Norton DP (2004) Strategy Maps: Converting intangible assets into tangible outcomes Boston. Research Technology Management.

14. Moon T (2010) Organizational Cultural Intelligence: Dynamic Capability Perspective. Group \& Organization Management 35: 456-493.

15. Chung LH, Gibbons PT (1997) Corporate Entrepreneurship: The Roles of Ideology and Social Capital. Group \& Organization Management 22: 10-30.

16. Yazdifar H, Askarany D (2009) A comparative investigation into the diffusion of management accounting innovations in the UK, Australia and New Zealand. Chartered Institute of Management Accountant (CIMA) 5: 1-11.

17. Rhodes A (2016) The relation between earnings-based measures in firm debt contracts and CEO pay sensitivity to earnings. Journal of Accounting and Economics 61: 1-22.

18. Christesen DA (2008) The Impact of Balanced Scorecard Usage on Organization Performance. Dissertations \& Theses - Gradworks, pp: 1-109.

19. Lawrie G, Cobbold L (2004) Third-generation balanced scorecard: evolution of an effective strategic control tool. International Journal of Productivity and Performance Management 53: 611-623.

20. Neely A, Marr B, Roos G, Pike S, Gupta O (2003) Towards the Third Generation of Performance Measurement. Controlling 3: 129-135.

OMICS International: Open Access Publication Benefits \&

\section{Features}

Unique features:

- Increased global visibility of articles through worldwide distribution and indexing

- Showcasing recent research output in a timely and updated manner

Special issues on the current trends of scientific research

Special features:

- $700+$ Open Access Journals

$50,000+$ editorial team

Rapid review process

Quality and quick editorial, review and publication processing

Indexing at major indexing services

Sharing Option: Social Networking Enabled

Authors, Reviewers and Editors rewarded with online Scientific Credits

Befter discount for your subsequent articles

Submit your manuscript at: http://www.omicsgroup.org/iournals/submission
Citation: Askarany D, Yazdifar $\mathrm{H}$ (2017) Management Accounting and the Shortcomings of Current Performance Measurement Systems. Int J Account Res 5: 146. doi: $10.4172 / 2472-114 X .1000146$ 